\title{
Extent and Rate of Deforestation and Forest Degradation (1986-2016) in West Bugwe Central Forest Reserve, Uganda
}

\author{
Fatuma Mutesi $\mathbb{D}$, ${ }^{1}$ John Robert Stephen Tabuti $\mathbb{D}^{2},{ }^{2}$ and David Mfitumukiza ${ }^{1}$ \\ ${ }^{1}$ Makerere University, Department of Geography, Geo-Informatics and Climatic Sciences, \\ College of Agricultural and Environmental Sciences (CAES), P.O. Box 7062, Kampala, Uganda \\ ${ }^{2}$ Makerere University, Department of Environmental Management, College of Agricultural and Environmental Sciences (CAES), \\ P.O. Box 7062, Kampala, Uganda \\ Correspondence should be addressed to Fatuma Mutesi; mutesi.fatuma@caes.mak.ac.ug
}

Received 18 July 2020; Revised 12 April 2021; Accepted 18 October 2021; Published 20 November 2021

Academic Editor: Thomas Campagnaro

Copyright (C) 2021 Fatuma Mutesi et al. This is an open access article distributed under the Creative Commons Attribution License, which permits unrestricted use, distribution, and reproduction in any medium, provided the original work is properly cited.

\begin{abstract}
Understanding the extent of land cover change and the forces behind land cover changes is essential in designing appropriate restoration strategies. Land cover changes at local scales or the factors that lead to cover change have not been documented for much of Uganda. We undertook this study in West Bugwe Central Forest Reserve (WBCFR) to fill this gap. We used remote sensing to determine land cover changes for a 30-year period, 1986-2016, and an interview survey to investigate the drivers of these changes. Our results show that the forest in this reserve has declined extensively by over $82 \%$ from 1,682 ha to 311 ha corresponding to an average change of $-1.18 \%$ per year. The wetland has also been extensively degraded. Both the forest and wetland have transitioned into shrub land. The key drivers that have been highlighted by the survey are poverty (86\%), population growth (56\%), and associated harvesting of woody products (86\%) for subsistence and income generation. We conclude that the forest in WBCFR has been extensively and rapidly deforested and degraded by humans.
\end{abstract}

\section{Introduction}

Forests are vital to human wellbeing and for environmental health. They sustain human livelihoods by providing important goods such as medicines, edible fruits, game meat, and incomes for more than a billion people [1]. Over 3 billion cubic meters of wood are harvested annually from forests for use as fuelwood and shelter. About 2.4 billion people cook with wood fuel [1], and at least 1.3 billion people rely on forest products for shelter [2]. Forests also support industries, formally employing about 13.2 million people across the world and informally at least another 41 million [2]. Similarly, forests provide about $20 \%$ of income for rural households in developing countries $[1,3]$. They also provide cultural services that include spiritual wellbeing. Lastly, forests safeguard the environment by providing regulating services such as carbon sequestration that is vital for climate change mitigation. This mitigation function is believed to be cheaper than those in other sectors [4].
Forests over most of sub-Saharan Africa are subject to deforestation and degradation through conversion into other vegetation or land cover forms [5]. Deforestation involves clearance of stand of trees from land which is then converted to nonforest use such as farm, ranches, or urban use. Forest degradation involves a reduction or loss of biological or economic productivity and complexity of forest ecosystems resulting in long-term reduction of overall supply of benefits from forest which includes wood, biodiversity, and other products or services [6]. In the period 1990-2015, total global forest cover reduced by $3 \%$, from $4128 \mathrm{Mha}$ to $3999 \mathrm{Mha}$ [7]. Forest loss is the greatest in the tropics particularly Africa. In 1990-2015, 7 million hectares of forest were lost in the tropical region [5]. In Uganda, forest cover has been declining, noticeably between 1990 and 2015 [8]. Uganda's forest cover dropped from 4.9 million hectares in 1990 to 3.6 million and 1.9 million hectares in 2005 and 2015, respectively [9]. Forests in Uganda have been subjected to land cover transitions including agriculture, 
grassland, pasture land, agroforestry, shrubland, and urban encroachments [10].

Factors that threaten forests are many, chief among which are land use change and associated land cover alterations [11]. Deforestation and degradation are results of both proximate and underlying drivers [10]. Proximate causes of deforestation include human activities with direct impacts on forest cover, such as agricultural expansion, urban growth, infrastructure development, and mining [11]. Humans clear tracts of forests to get land for agriculture [12]. In terms of scale, proximate drivers are seen to operate at the local level [13].

The underlying causes of deforestation relate to macrolevel interactions of economic, demographic, technological, social, cultural, and political factors that may operate at some distance from the forests they affect such as lack of land use planning and ineffective law enforcement $[13,14]$. Underlying causes stem from multiple scales: international (e.g., commodity markets and commodity price dynamics) and national (e.g., economic developments strategies, population growth, governance and local circumstances such as poverty and unclear land tenure) [14]. A significant economic factor is that of global markets for commodity crops, such as palm oil and cocoa [12, 15]. Commodity crop growing is expanding in all parts of the world. In Uganda, it grew by $69.1 \%$ between 2000 and 2013 [15]. The growth of commodity and other agricultural crops requires much land. The land required to grow these crops comes from forests [11]. According to Gibbs et al. [16], 55\% of new land for the growth of commodity crops was carved from intact forests between 1980 and 2000. A further 28\% came from disturbed forests. Worldwide, the demand for agricultural products is expected to increase by $50 \%$, and most of this land is going to come from forests. These factors are not uniform and vary between and within sites. For this reason, local scale drivers of land cover change must be determined in order to design appropriate interventions.

Uganda's protected areas are under increasing threats from deforestation and degradation, owing to an increasing human population $[17,18]$. However, there is currently little work that has assessed land cover change (LCC) for most forested areas in Uganda, and we lack information on the extent and rate of forest loss at local levels [10, 18]. A few studies have been conducted in western Uganda concerning LCC. One such study was conducted in Budongo and Bugoma Forest Reserves [19] and showed that there was a $10.7 \%$ loss in total forest cover at the landscape scale between 1985 and 2014. Another study in Bwindi Impenetrable National Park [20] showed that while the forest declined by close to $8 \%$, small-scale agriculture had expanded by $13.9 \%$. Otieno and Buyinza [21] looked at the role of collaborative forest management as a strategy to control deforestation in WBCFR. Further still, Otieno et al. [22] tried to assess the domestic uses of forest resources in WBCFR, the illegalities in the reserve, and the interventions of curbing those illegal activities. This study complements these earlier studies. The study was conducted in West Bugwe Central Forest Reserve (WBCFR) found in eastern Uganda. The objectives for this study were to assess LCC for WBCFR and the drivers influencing the change.

\section{Study Area and Methods}

West Bugwe Central Forest Reserve (WBCFR) is found in eastern Uganda between $00^{\circ} 28^{\prime} 30-0^{\circ} 35^{\prime} 30 \mathrm{~N}$ and $33^{\circ} 54^{\prime} 30^{\prime \prime}-35^{\circ} 5^{\prime} 0^{\prime \prime} \mathrm{E}$ (Figure 1). The reserve covers a total area of 3,780 hectares and has three management blocks, namely, Central block (2,995 ha), Amonikakinei (158 ha), and Sitambogo (627 ha). The reserve is approximately $21 \mathrm{~km}$ from Busia town and close to the border between Uganda and Kenya. It is located within three administrative jurisdictions, namely, Busitema, Bulumbi, and Buyanga subcounties. All three subcounties are in Samia Bugwe North County, Busia district. The reserve is bisected by the Kampala-Malaba highway. The topography of the reserve is generally flat, at an altitude of $1000-1235 \mathrm{~m}$ above the sea level. The reserve is described as moist Combretum wooded grassland.

The local community surrounding the reserve subsists on agricultural production with $69 \%$ of the population dependent on crop agriculture for their livelihood, while $27 \%$ depends on wage employment [23]. The community also engages in charcoal burning for income generation, as well as mining and quarrying activities. Most of the households (94\%) in the community depend on fuelwood for cooking. The population density is high with 440 people $/ \mathrm{km}^{2}$ and has been growing at a rate of $2.7 \%$ per annum. In 2014, Busia had a population of 323,662 compared to 225,008 in 2002 [24]. Most of the population is young, with $62 \%$ less than 20 years of age. The community has low levels of formal education. This suggests a high dependence on the reserve for subsistence and income generation [25].

\section{Methods}

To determine the land cover changes in WBCFR, an image time series analysis was conducted to establish the various land cover classes and the transitions between the different classes for the period 1986-2016. The main activities undertaken under land cover change analysis were image acquisition, ground truthing, image classification, accuracy assessment, and land cover change detection analysis. We used a social survey approach to determine the drivers for land cover change (LCC).

3.1. Image Acquisition and Ground Truthing. Cloud free images (path 170 and row 060) were downloaded from https://www.earthexplorer.usgs.gov. The United States Geological Survey website provides an option to choose the level of cloud cover. We were therefore able to select images with cloud cover less than $10 \%$. All the images were for wet seasons (March-April). The images together with their dates of acquisition are Landsat MSS (31/03/1986), Landsat TM (02/04/1995), Landsat ETM+ (06/03/2006), and Landsat OLIS/TIRS (11/04/2016). We intended to have an image acquired in 1996; however, this was not available. The 


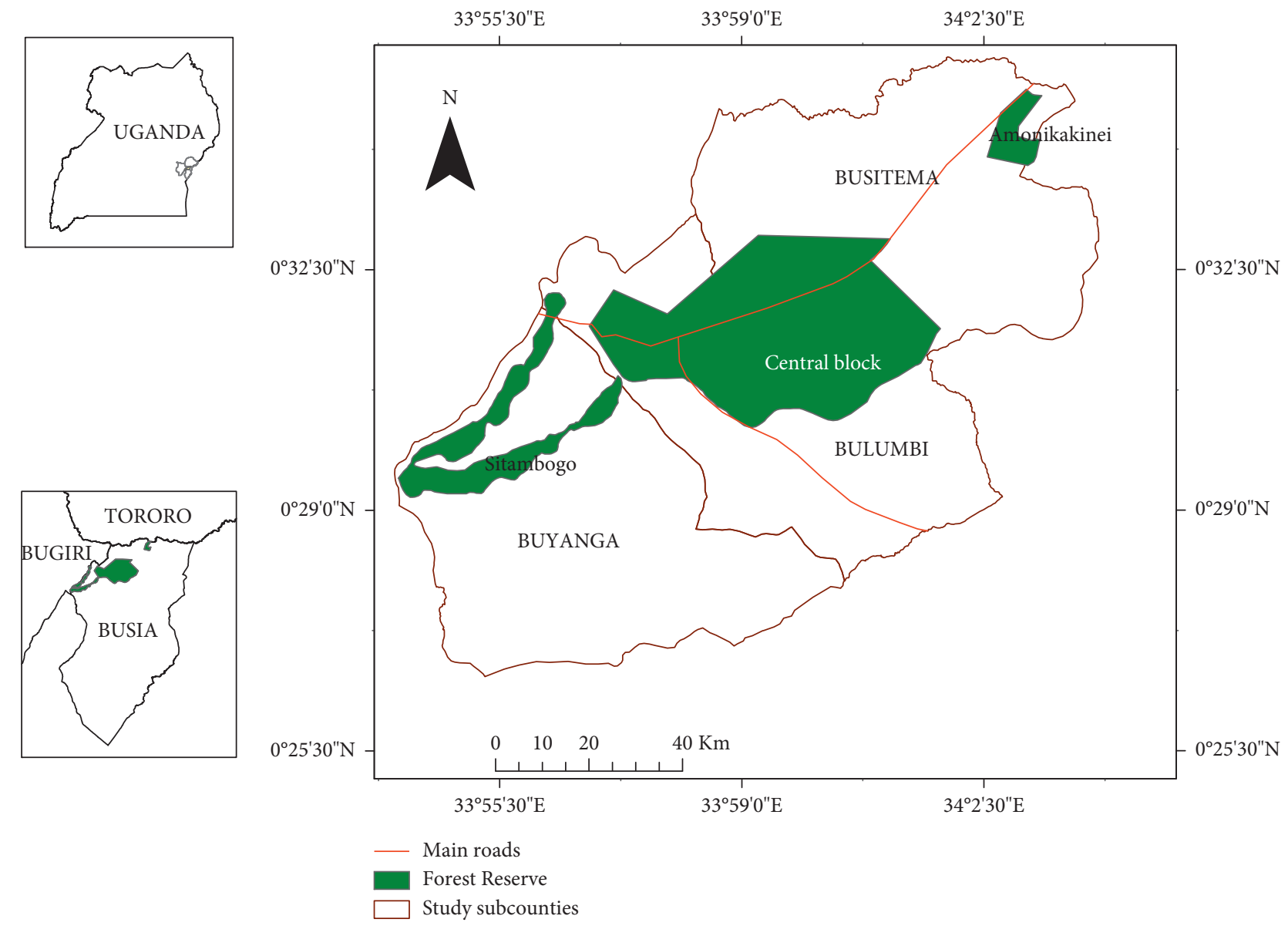

Figure 1: West Bugwe Central Forest Reserve. Inset is location of WBCFR within Busia district (lower panel on the left) and in Uganda (top panel on the left).

use of a 10-year range was considered appropriate for change assessment from Landsat images. This is found in other previous related studies, which are based on longer time series [20, 26, 27]. All Landsat 7 images collected after May 31,2003 , have gaps because the scan line corrector failed. However, these data are still useful and maintain the same radiometric and geometric corrections as data acquired prior to the scan line corrector failure. Using the "Fill no data" function, gap filling was done in QGIS 3.14 to rectify the scan collector problem in ETM+2006 prior to image classification. The data to fill the gaps were obtained from the gap mask that was contained in the image of 2006.

The ground truthing was aimed at obtaining data for running supervised land cover classification and accuracy assessment of the resulting maps. In preparation for ground truthing, unsupervised classification was carried out on the 2016 Landsat OLIS/TIRS (17/08/2016) image using ERDAS Imagine $^{\circledR} 2014$ software. This classification was informed by field experience and existing maps on land cover and land use [28] and was based on the widely accepted red, green, and blue (432) image bands false color composite for vegetation discrimination. A random function was used in ArcMap 10.4, where the forest reserve was divided into 1 square kilometer grids. The grids were labelled, and the first 200 grids were selected to be visited during the ground truthing exercise to establish the existing land cover classes. While in the field, 120 points were accessed and characterized.

The vegetation strata (spectral classes of the 2016 dataset) were used as the basis for selecting data collection sampling sites. The sampling sites for land cover data collection were selected using stratified random sampling. Twenty sampling points were randomly established in each of the six strata to make a total of 120 sampling points (Figure 2). At each point, a $30 \times 30$ plot was established. The vegetation life form (tree, shrub, or herbaceous) was recoded for each plot. Plant height and percentage cover were also estimated and recorded. Plant height was visually estimated, specifically, to determine if a stratum qualified to be a forest or not, with a minimum of $5 \mathrm{~m}$ being the threshold for a forest. Each sampling plot was assigned a field land cover class based on the predominant vegetation life form, plant cover, and height according to [29] the classification scheme. Half of the sampling plot data (60) were used as training samples, and the other half for accuracy assessment as described in 3.3.

3.2. Land Cover Classification. The training data samples collected during the ground truthing exercise were loaded into ERDAS Imagine ${ }^{\circledR} 2014$ system and used to generate 


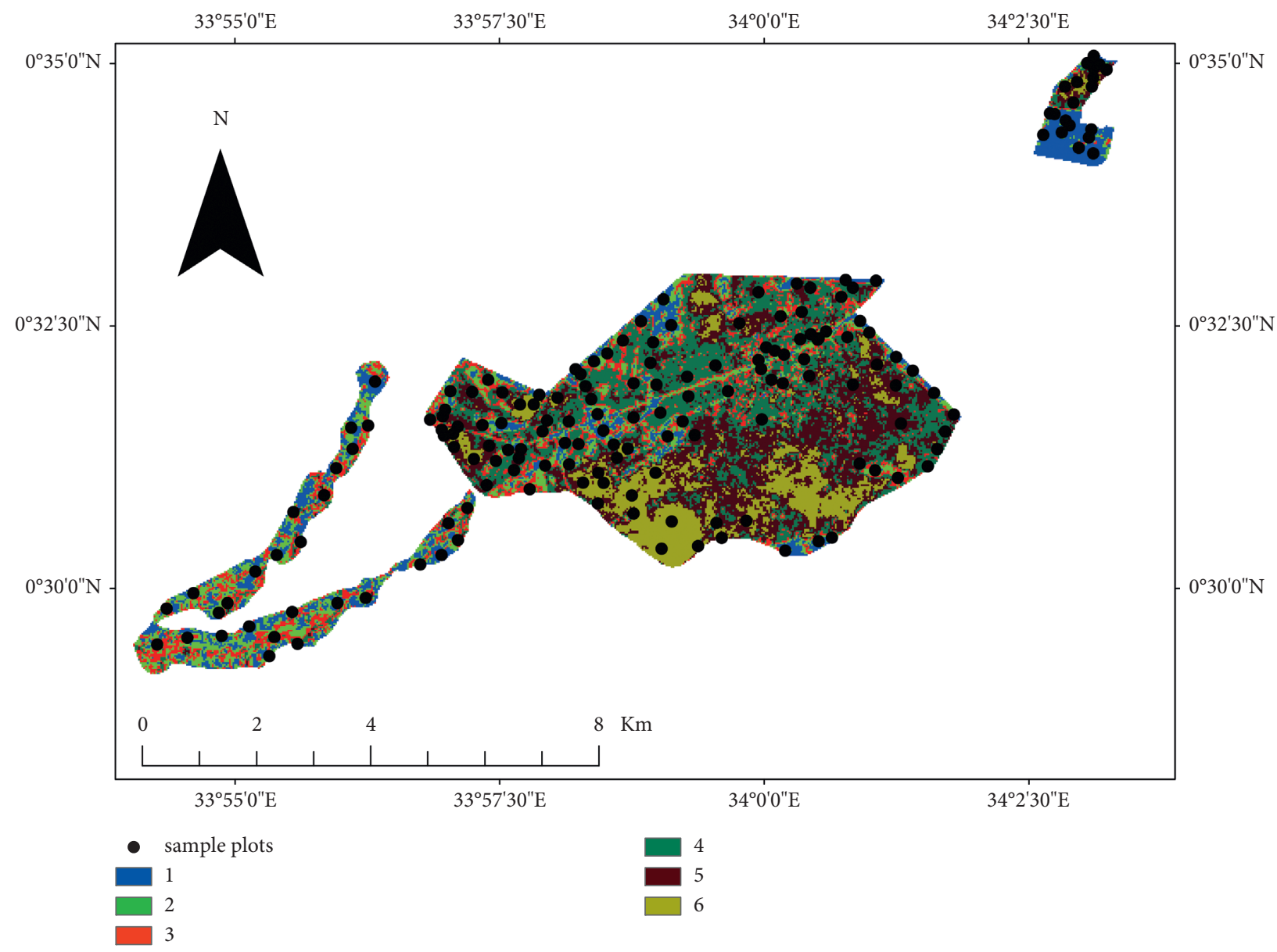

FIGURE 2: Vegetation sampling strata and distribution of sampling points.

classification signature files for coming up with land cover classes from supervised image classification. This classification was carried out using the maximum likelihood classifier. All images for the different years $(1986,1995,2006$, and 2016) were classified based on the FAO [29] classification scheme to generate respective land cover maps with six classes, i.e., forest, wetland, shrubland, built-up area, grassland, and farmland (Table 1). Mixed pixels in the resulting maps were minimized by dissolving all clusters of less than 16 pixels into the dominant land cover classes in which they were contained [30]. The effect of dissolving the mixed pixels was assumed to be equally distributed in all cover classes [31].

3.3. Accuracy Assessment. Accuracy assessment was performed using an error matrix to determine the level of reliability of the maps resulting from the supervised classification. The assessment involved an evaluation of the matrix of field data classes of 60 sampling points and map classes resulting from supervised classification [32]. The accuracy for the images of the different years was 91\% (1986), $86.7 \%$ (1995), 88.3\% (2006), and 81.6\% (2016), with overall kappa ranging $0.78-0.9$ (Table 2). This implies a strong agreement between the classification results and ground truth data. Kappa coefficient, a statistical measure of agreement, was used as a measure of reliability between the classification results and the ground truth data. It is calculated as given in Appendix 2.

3.4. Land Cover Change Detection. Change detection or extent analysis was done to quantify the changes associated with land cover in the landscape. The extent analysis was based on changes in proportions of land cover classes and the transitions from one cover class to another. The rate of change considered the proportion of change between the time periods of the different images. We also determined the annual average rates of change (AARC) and percentage change.

Annual average rates of change were obtained as the differences in percentage change between any two-time periods divided by the number of years in the periods. For example, AARC between 1986 and 1995 was computed as the difference in a given land cover between 1986 and 1995 divided by the number of years between the two periods multiplied by 100 . Land cover transitions were determined using a land change modeler in TerrSet 18.2. The process involved superimposing land cover map pairs for consecutive years (e.g., 1986 and 1995) to generate a matrix showing transitions between different land cover classes. The analysis also resulted in maps showing changes in spatial extent from one cover to another, for example, from forest to grassland. 
TABLE 1: FAO classification scheme [29].

\begin{tabular}{|c|c|}
\hline Class & Description \\
\hline Forest & Land spanning 0.5 ha with trees greater than $5 \mathrm{~m}$ and canopy cover of above $10 \%$ \\
\hline Shrubland & Area dominated by shrubs and with sparse grasses and herbs \\
\hline Wetland & Areas with water on the surface \\
\hline Grassland & Areas dominated by grass. Trees and shrub may be present but with sparse cover \\
\hline Built-up & Roads or lanes, buildings, mines, and quarry sites \\
\hline Farmland & Area under arable crops, perennial crops, and land under fallow \\
\hline
\end{tabular}

TABLE 2: Image classification accuracy assessment for the different images. All assessments are in percentage.

\begin{tabular}{|c|c|c|c|c|c|c|c|c|}
\hline \multirow{2}{*}{ Land cover } & \multicolumn{2}{|c|}{1986 MSS } & \multicolumn{2}{|c|}{1995 TM } & \multicolumn{2}{|c|}{2006 ETM+ } & \multicolumn{2}{|c|}{2016 OLIS/TIRS } \\
\hline & Producer's (\%) & User's (\%) & Producer's (\%) & User's (\%) & Producer's (\%) & User's (\%) & Producer's (\%) & User's (\%) \\
\hline Forest & 100 & 70 & 100 & 40 & 100 & 50 & 100 & 80 \\
\hline Shrubland & 66.6 & 80 & 88.8 & 80 & 100 & 80 & 85.7 & 60 \\
\hline Farmland & 100 & 100 & 83.3 & 100 & 90.9 & 100 & 87.5 & 70 \\
\hline Wetland & 66.9 & 100 & 100 & 100 & 90.9 & 100 & 90 & 90 \\
\hline Grassland & 100 & 100 & 83.3 & 100 & 66.66 & 100 & 64.2 & 90 \\
\hline Built-up & 100 & 100 & 66.9 & 100 & 100 & 100 & 76.9 & 100 \\
\hline Overall accuracy (\%) & 91.7 & & 86.7 & & 88.3 & & 81.6 & \\
\hline Overall kappa & 0.9 & & 0.84 & & 0.86 & & 0.78 & \\
\hline
\end{tabular}

\subsection{Determination of Drivers for Land Cover Change.} Our second objective was to determine the drivers of land cover change (LCC). To do this, we carried out a crosssectional household survey using a questionnaire. We also conducted eight key informant interviews (KII) using a checklist of questions and two focus group discussions (FGDs). The checklist of issues consisted of observed changes in WBCFR, activities carried out in the reserve by people living adjacent to the reserve, and the factors driving LCC. The FGD and KII were conducted to triangulate the questionnaire survey data. Each of the two FGD had eight participants, aged 50-58 years. FGDs were held separately for male and female participants. The FGD covered the historical trends of WBCFR, perceptions of the status of WBCFR between 1986 and 2016, and causes of land use and cover changes.

A total of 180 respondents were interviewed in the household survey (HHS). These were selected using a multistage sampling procedure with subcounties (the immediate lower administrative units that make up a county) as the primary sampling units. From each of the three subcounties (Busitema, Bulumbi, and Buyanga) neighboring the reserve, one parish was randomly selected. Two villages were selected randomly in each selected parish. For each selected village, a sampling frame of households was created. Thirty households were randomly selected from each selected village to make 180 respondents. The head of each household was interviewed using a semistructured questionnaire. In case he/she was absent, another mature person was interviewed instead. The semistructured questionnaire for the household survey covered socioeconomic characteristics of the respondent, activities carried out in the reserve, and factors responsible for LCC (Appendix 1). The socioeconomic variables of the respondents are given in Table 3 . The respondents were equally distributed among the genders, earned their livelihoods from small-scale agriculture, had lived around the forest reserve for periods exceeding 10 years, had lowly forms of education, and had large families. During the interviews, the respondents freely listed the activities carried out in the reserve and factors responsible for LCC. Social economic and demographic information was also recorded. Data from HHS were summarized into frequencies and means/modes.

\section{Results}

4.1. Land Cover Changes. Over the 30-year period (1986-2016), major land cover changes took place in West Bugwe Central Forest Reserve. The forest and wetland areas declined, while the shrub land increased in area. The forest declined from $43.6 \%$ to $8.1 \%$ of the land area (the percentage cover values are computed from data in Table 4 and Figure 3). Overall, for the three decades, the forest experienced a percentage cover loss of $82 \%$. For the wetland, the decline was $65 \%$. Farmland and built-up area increased by $160 \%$ and $71 \%$, respectively (Table 4 ). In the same period, the shrub land cover grew by $148 \%$. The average annual rate of change for the 30-year period for the forest and wetland were $-1.18 \%$ and $-0.23 \%$, respectively (Table 5 ). In the same period, this rate was $1.17 \%$ for the shrubland (Table 5).

Analysis of these changes at the decade level reveals that in the first decade under study here (1986-1995), the forest and grassland shrank faster than any other land cover class, $-37 \%$ and $-53 \%$ (the percentage cover values are computed from data in Table 4). However, the grassland gained in the succeeding decade by more than $81 \%$. In the last decade (2006-2016), the forest and wetland shrank by $68 \%$ and $70 \%$, respectively. In these two decades where the forest, grassland, and wetland shrank, the shrub land cover increased by 84\% (1986-1995) and 49\% (2006-2016), respectively. At all 
TABle 3: Socioeconomic characteristics of the respondents.

\begin{tabular}{lc}
\hline Demographic characteristics & Percentage \\
\hline Sex & \\
Female & 52 \\
Male & 48 \\
Household source of income & \\
Small-scale agriculture & 86 \\
Trade & 9 \\
Salaried employment & 2 \\
Casual labour & 3 \\
Years spent in the area & \\
Less than a year & 1 \\
1-10 years & 14 \\
11-20 years & 15 \\
21-30 years & 24 \\
Above 31 & 46 \\
Education level & \\
Primary & 62 \\
Secondary & 16 \\
Tertiary & 3 \\
No education & 19 \\
Household size & \\
Less than 5 people & 23 \\
More than 5 people & 77 \\
\hline
\end{tabular}

TABle 4: Percent land cover changes in West Bugwe Central Forest Reserve for the period 1986-2016.

\begin{tabular}{lcccc}
\hline Land cover & $1986(\%)$ & $1995(\%)$ & $2006(\%)$ & $2016(\%)$ \\
\hline Forest & 43.6 & 27.5 & 25.4 & 8.1 \\
Shrubland & 24.7 & 45.4 & 40.1 & 59.9 \\
Wetland & 10.7 & 10.6 & 12.4 & 3.7 \\
Grassland & 16 & 7.5 & 13.6 & 17.9 \\
Farmland & 2.5 & 5.5 & 6.4 & 6.5 \\
Built-up & 2.1 & 3.4 & 2.2 & 3.6 \\
\hline
\end{tabular}

times, the cultivated area (farmland) was growing. It increased by $120 \%$ in the first decade. The above trends are complemented by the transition changes that show that the forest changed into shrub land. Grassland and wetlands also transitioned into shrub land. In general, our results indicate that the forest and wetland transitioned into shrub land. In addition, the most significant changes took place in 1986-1995 and in 2006-2016. The bolded figures show how much the land cover remained unchanged (Table 6).

4.2. Land Cover Change Drivers. From the household survey, we established that all respondents had observed decrease in the forest area from what it was in 1986. No single respondent reported increase in the forest size. Fifteen drivers of deforestation were mentioned by the respondents. The key ones were poverty (86\%), charcoal burning (86\%), firewood harvesting $(70 \%)$, population increase $(56 \%)$, timber extraction $(52 \%)$, and fire (51\%). The number in parentheses shows the proportion of respondents that mentioned the driver.

Discussions with key informants confirmed the above factors as major drivers of land cover change. For instance, one key informant stated that "Fuel extraction is closely linked to the high levels of poverty among the communities adjacent to West Bugwe Forest Reserve. People lack alternative livelihood initiatives that can support their needs and their families. As a result, they look at the reserve as the only source of livelihood and thus engage in activities like tree cutting for charcoal and firewood." (key informant participant \#3).

Surprisingly, crop agriculture was not considered an important driver of deforestation. Nonetheless, the local community encroaches on the reserve land, but when the law enforcers find crop gardens, they destroy them.

The FGDs elaborated further on the trends. According to the FGDs, in the period 1986-1995, there was extensive illegal logging by armed loggers. At that time, the regulatory body, the National Forest Authority (NFA), was not deployed in the forest. An NFA post was established in Tororo (about $21 \mathrm{~km}$ from the reserve) in the period 1995-2006.

Other factors described in KII and FGD included invasion by an invasive species (obwengere, unidentified), a forest fire in 2015, weak law enforcement, proximity to the international border with Kenya, weak laws and government policy, good roads, and closeness to urban centers (Busia, Tororo, and Malaba towns). Concerning law enforcement, it was reported during the KII that there were too few staff to manage the reserve. The staff managing the reserve comprises of two forest supervisors, two environmental police officers and two patrolmen. This means that monitoring and patrols can only be conducted at the periphery of the reserve. Furthermore, the environmental police has only been recently deployed in the reserve. The staff also have many other challenges that include (1) poor facilitation with equipment such as protective clothing or motorcycle for patrols and other forestry management duties and (2) late disbursement of wages; for instance, patrolmen claimed that they were last paid in 2015.

Governance challenges are also apparent and include conflict between the local bye-laws and the national policy and national laws and between the environmental law and the local government Act. Whereas the environmental law is aimed at conservation, the local government Act is looked at as a legal basis for generating revenue from forests by local governments. So, while NFA restricts charcoal making, the local government licenses people to burn, sell, and transport charcoal to generate local revenue. Another governance challenge is that there are two law enforcement organizations in the same reserve, the environmental police and NFA law enforcers. There is also parallel reporting, in the sense that the environmental police reports through the police hierarchy and not to NFA. This has potential to create conflicts. In summary, the proximate or direct drivers of deforestation were resource extraction (fuelwood and timber). The underlying drivers were poverty, population growth, governance issues, and management constraints.

\section{Discussion}

West Bugwe Central Forest Reserve has been severely deforested and also degraded at a very fast rate. The forest cover has been severely curtailed with a loss of $82 \%$ 


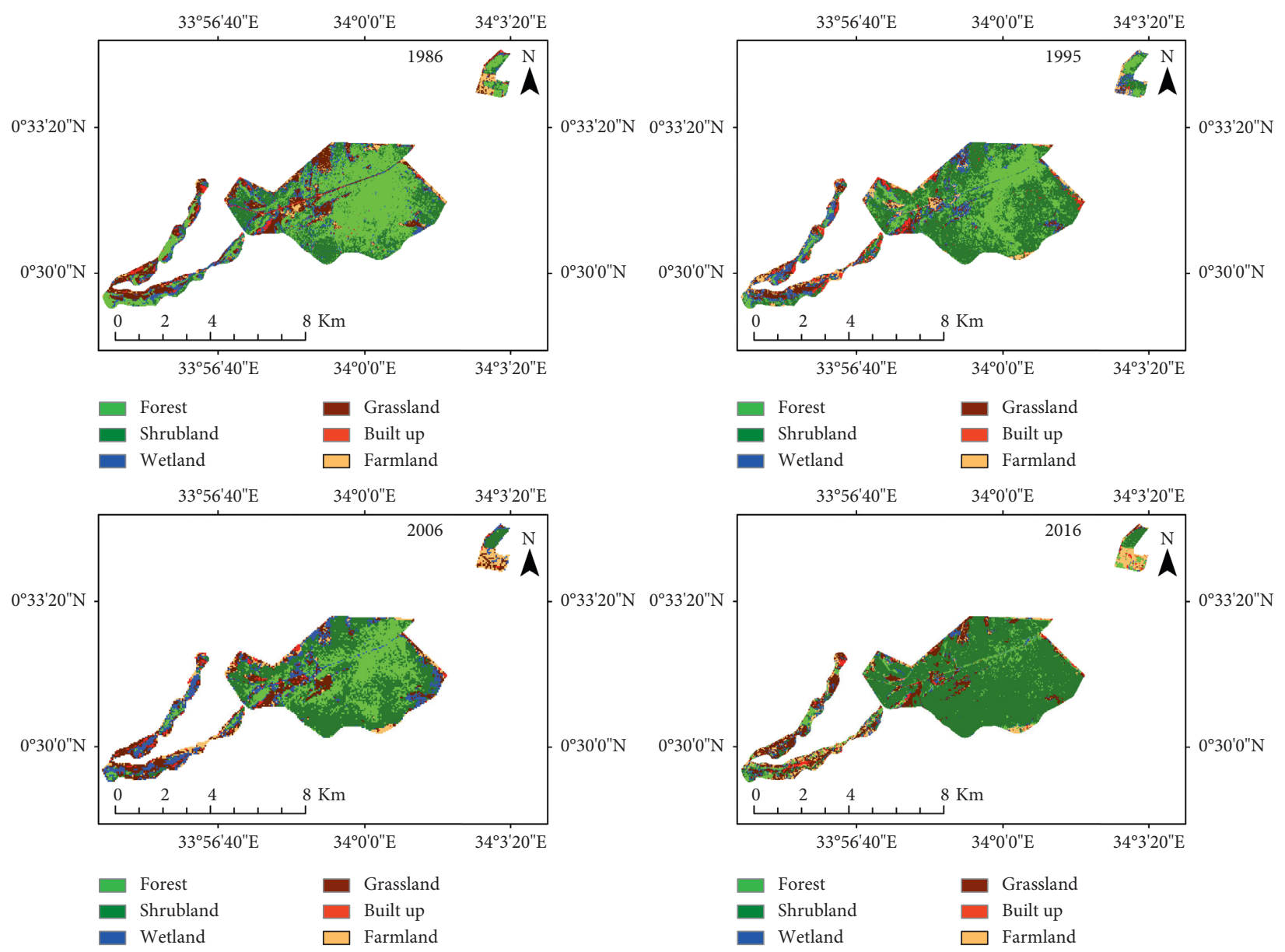

Figure 3: Land cover maps for the period 1986-2016 for West Bugwe Central Forest Reserve.

TABLE 5: Average annual rates of change in percentage between the years 1986, 1995, 2006, and 2016 for the classified land cover classes in West Bugwe Central Forest Reserve.

\begin{tabular}{lcccc}
\hline Land cover & $1986-1995(\%)$ & $1995-2006(\%)$ & 2006-2016 (\%) & Average annual rate of change (1986-2016) (\%) \\
\hline Forest & -1.78 & -0.19 & -1.73 & -1.18 \\
Shrubland & 2.3 & -0.48 & 1.98 & 1.17 \\
Grassland & -0.94 & 0.55 & 0.43 & 0.06 \\
Wetland & -0.01 & 0.16 & -0.87 & -0.23 \\
Farmland & 0.33 & 0.08 & 0.01 & 0.13 \\
Built-up & 0.14 & -0.11 & 0.14 & 0.05 \\
\hline
\end{tabular}

compared to what it was in 1986 . The rate of loss of $1.27 \%$ is far higher than the one reported by NFA for protected areas in Uganda of $0.7 \%$ [28]. This implies that the forest is at the verge of disappearing. These rates were highest in the periods $1986-1995(1.9 \%)$ and $2006-2016(1.72 \%)$. It is not clear why these two decades had the most extensive forest loss or why the period 1996-2006 had a decline in forest loss $(0.19 \%)$.

The forest has transitioned or has degraded into shrubland. The degradation of forests into shrubs is a common trend in sub-Saharan Africa [12]. In Uganda, land cover transitions are not unique to WBCFR. However, the trend of transitions recorded in this study is different from what has been reported by other studies. Twongyirwe et al. [19] reported a transition of forest into farmland and built-up areas in Budongo and Bugoma Forests contrary to what this study reports, where forest transitioned to shrub land. Twongyirwe et al. [20] also reported increase in farmland at the expense of forest and woodland in Bwindi Impenetrable Forest. The loss of the forest may potentially lower the capacity of this ecosystem to provide forest products required by the local community or to sequester carbon [33-36].

Also, worrying in the current case is that the wetland has been heavily degraded. This means that the key regulating services that are important to humans like control of flooding and aquifer recharge have been lost [17, 33, 37]. Conversion of wetland to other land covers has been reported in other areas of Uganda $[35,38]$. The only difference in this study is 
TABLE 6: Transition matrices for the periods 1986-1995, 1995-2006, and 2006-2016 in hectares.

\begin{tabular}{|c|c|c|c|c|c|c|c|c|}
\hline \multicolumn{9}{|c|}{$\begin{array}{c}\text { Time period } 1986-1995 \\
1995\end{array}$} \\
\hline \multirow{8}{*}{1986} & Land cover & Forest $(\mathrm{Ha})$ & Shrubland (Ha) & Grassland $(\mathrm{Ha})$ & Wetland (Ha) & Farmland $(\mathrm{Ha})$ & Built up (Ha) & Total $1986(\mathrm{Ha})$ \\
\hline & Forest & 716 & 787 & 21 & 80 & 18 & 11 & 1633 \\
\hline & Shrubland & 197 & 805 & 13 & 22 & 20 & 31 & 1088 \\
\hline & Grassland & 57 & 105 & 141 & 166 & 93 & 32 & 594 \\
\hline & Wetland & 62 & 141 & 46 & 6 & 27 & 34 & 316 \\
\hline & Farmland & 1 & 12 & 22 & 26 & 10 & 3 & 74 \\
\hline & Built up & 3 & 4 & 27 & 14 & 18 & 9 & 75 \\
\hline & Total 1995 & 1036 & 1854 & 270 & 314 & 186 & 120 & 3780 \\
\hline \multicolumn{9}{|c|}{ Time period $1995-2006$} \\
\hline \multirow{8}{*}{1995} & & Forest $(\mathrm{Ha})$ & Shrubland (Ha) & Grassland $(\mathrm{Ha})$ & Wetland (Ha) & Farmland $(\mathrm{Ha})$ & Built up (Ha) & Total $1995(\mathrm{Ha})$ \\
\hline & Forest & 521 & 424 & 25 & 58 & 10 & 1 & 1039.5 \\
\hline & Shrubland & 410 & 1051.3 & 102 & 138 & 49 & 2 & 1752.3 \\
\hline & Grassland & 1.8 & 6 & 161 & 72 & 32 & 25 & 297.8 \\
\hline & Wetland & 20 & 30 & 123 & 138.2 & 47 & 10 & 368.2 \\
\hline & Farmland & 0.8 & 4 & 81 & 27 & 16.7 & 20 & 149.5 \\
\hline & Built up & 1.8 & 9.5 & 56 & 24 & 18 & 63.9 & 173.2 \\
\hline & Total 2006 & 955.4 & 1524.8 & 548 & 457.2 & 172.7 & 121.9 & 3780 \\
\hline \multicolumn{9}{|c|}{$\begin{array}{c}\text { Time period } 2006-2016 \\
2016\end{array}$} \\
\hline \multirow{8}{*}{2006} & & Forest $(\mathrm{Ha})$ & Shrubland $(\mathrm{Ha})$ & Grassland $(\mathrm{Ha})$ & Wetland $(\mathrm{Ha})$ & Farmland (Ha) & Built up (Ha) & Total $2006(\mathrm{Ha})$ \\
\hline & Forest & 102 & 753 & 23 & 9 & 11 & 8 & 906 \\
\hline & Shrubland & 92 & 1378.1 & 44 & 10 & 29 & 14 & 1567.1 \\
\hline & Grassland & 17 & 73 & 56.6 & 55 & 81 & 46 & 328.6 \\
\hline & Wetland & 36 & 116 & 218 & 216 & 56 & 18 & 660 \\
\hline & Farmland & 5.4 & 13 & 84 & 21 & 9 & 33 & 165.4 \\
\hline & Built up & 0.36 & 1 & 43 & 7 & 10 & 91.6 & 152.9 \\
\hline & Total 2016 & 252.76 & 2334.1 & 468.6 & 318 & 196 & 210.6 & 3780 \\
\hline
\end{tabular}

Areas in bold did not change land cover class.

that wetland has converted to shrubland and grassland unlike in other studies where wetland has converted to farmland $[35,37]$. The decline in the built-up area could be due to settlement evictions in areas surrounding the reserve, as reported by Otieno and Buyinza [21]. For all land cover classes, there were what appeared to be stochastic changes with no particular pattern in the different decades. It is not easy to distinguish what drives these erratic changes among the different drivers discussed.

The main proximate drivers for the loss of the forest are extractive human activities aimed at satisfying subsistence needs and to generate incomes. Heaps of firewood and charcoal both for sale and domestic use during the survey were observed. These factors have been reported to have contributed to forest loss in other areas [19, 21, 27, 39, 40]. Unlike in other areas $[19,21,39]$, crop and livestock agriculture were not found to be important factors of forest loss and degradation. Indeed, agriculture was declining. The growing law enforcement seems to be responsible for this decline in crop agriculture.

For now, there appears to be few pragmatic alternatives to address the needs and demand for forest products for subsistence and income generation for communities around WBCFR. One possible intervention is to introduce biomass fuel efficiency and alternative fuel options, e.g., liquefied petroleum gas around the reserve to reduce demand for fuelwood. The other feasible intervention is to promote tree planting outside the reserve including agroforestry practices. This will go a long way in reducing pressure on the forest reserve.

The underlying drivers are poverty in the community, population growth, as well as protected area governance and management challenges. These drivers were reported by Otieno and Buyinza [21] and Otieno et al. [39]. Population growth has been reported to be responsible for land cover change elsewhere [10, 26, 40]. Management of protected areas is a common challenge in many parts of the world and is influenced by the resources that are available to government [26, 27, 39]. These are usually limited (insufficient staff and their facilitation, e.g., trucks for monitoring and law enforcement) [21]. These challenges demand resources that are currently unavailable.

Clearly, the forest needs to be restored to provide ecosystem and provisioning services such as climate change mitigation through carbon sequestration and forest products to the neighboring community. There should be deliberate efforts to reafforest the reserve, improve its management, and initiate activities that reduce demand for forest products, such as the abovementioned fuel efficiency approaches.

The government and its agencies, e.g., the National Forest Authority, cannot do all this alone because they are constrained by resources and staff. There is need to involve the local community and other stakeholders such as nonstate actors in 
governance and management of the reserve [21]. There are many advantages of collaborative forest management (CFM). Involving local stakeholders helps, among other things, to enlist support of local communities, ensure equitable sharing of forest benefits and to mitigate risks and costs that arise out of exclusionary forest management [41]. Collaborative forest management helps in developing a sense of ownership among the communities living around forest. Participation also increases local awareness, e.g., to understand the need to protect forests and environmental awareness. It also creates local institutional frameworks that can link remote rural communities to international and global frameworks [42, 43]. A good example where collaborative forest management has worked is Tororo Forest Reserve where it reduced conflict between the then Forestry Department and the Nyangole community in eastern Uganda. The Nyangole community was allowed access and withdrawal rights over the reserve, which created a feeling of ownership over the forest and a responsibility for the management of the reserve [44]. There is need, therefore, to understand the factors that would lead to effective CFM. For this, a stakeholder analysis will be highly desirable. The stakeholder analysis will be pivotal in determining stakeholder rights, interests, needs, benefits [41], and design of effective engagement based on well-defined stakeholder roles [45].

\section{Conclusion}

The forest cover of WBCFR declined significantly by $82 \%$ in the three decades covered by this study. Most of the forest has transitioned into shrubland according to the LCC detection analysis. The loss of the forest appears to have been caused by increase in human population and the associated demand for fuelwood. Interventions to control forest loss and undertake reafforestation must address the underlying drivers of poverty and population pressure on the reserve. This study has produced evidence of the extent and rate of forest loss in WBCFR. This information will guide policy makers and implementers in the necessary actions to improve the health of WBCFR.

\section{Data Availability}

The data used to support the conclusions of the study can be accessed from the authors' institutional server.

\section{Conflicts of Interest}

The authors declare that they have no conflicts of interest.

\section{Acknowledgments}

The authors thank the Government of Norway through NORAD and the NORHED project building capacity for REDD+ in East Africa for improved ecosystem health and for sustainable livelihoods in Eastern Africa (REDD-EA, UGA-13/0019) for funding this study. The Uganda National Council for Science and Technology granted permission to conduct the study (NS 511). The National Forestry Authority (NFA) also granted permission to access WBCFR. The authors also thank their fellow REDD-EA project scientists and the graduate fellows for their constructive ideas that enriched the study. The authors are grateful to Busia District Local Government, NFA officials in WBCFR, and residents of Busia district for the warm welcome and willingness to provide the required data for the study.

\section{Supplementary Materials}

Appendix 1. Semistructured questionnaire. Appendix 2. (Supplementary Materials)

\section{References}

[1] FAO, The State of the World's Forests 2018-Forest Pathways to Sustainable Development, FAO, Rome, Italy, 2018.

[2] FAO, State of the World's Forests-Enhancing the Socioeconomic Benefits from Forests, FAO, Rome, Italy, 2014.

[3] Y. Li, B. Mei, and T. Linhares-Juvenal, "The economic contribution of the world's forest sector," Forest Policy and Economics, vol. 100, pp. 236-253, 2019.

[4] J. E. M. Watson, T. Evans, O. Venter et al., "The exceptional value of intact forest ecosystems," Nature Ecology \& Evolution, vol. 2, no. 4, pp. 599-610, 2018.

[5] FAO, Global Forest Resources Assessment 2015: Desk Reference, FAO, Rome, Italy, 2015.

[6] FAO UNEP, The State of the World's Forests 2020: Forests, Biodiversity and People, FAO, Rome, Italy, 2020.

[7] R. J. Keenan, G. A. Reams, F. Achard, J. V. de Freitas, A. Grainger, and E. Lindquist, "Dynamics of global forest area: results from the FAO global forest resources assessment 2015," Forest Ecology and Management, vol. 352, pp. 9-20, 2015.

[8] NEMA, National State of the Environment Report 2016/17, National State of the Environment, Kampala, Uganda, 2017.

[9] UBOS, 2020 Statistical Abstract, Uganda Bureau of Statistics Kampala, Kampala, Uganda, 2020.

[10] J. Kilama Luwa, Y. Bamutaze, J.-G. Majaliwa Mwanjalolo, D. Waiswa, P. Pilesjö, and E. B. Mukengere, "Impacts of land use and land cover change in response to different driving forces in Uganda: evidence from a review," African Geographical Review, pp. 1-17, 2020.

[11] FAO, State of the World's Forests 2016. Forests and Agriculture: Land-Use Challenges and Opportunities, FAO, Rome, Italy, 2016.

[12] X.-P. Song, M. C. Hansen, S. V. Stehman et al., "Global land change from 1982 to 2016," Nature, vol. 560, no. 7720, pp. 639-643, 2018.

[13] H. J. Geist and E. F. Lambin, "Proximate causes and underlying driving forces of tropical deforestation: tropical forests are disappearing as the result of many pressures, both local and regional, acting in various combinations in different geographical locations," BioScience, vol. 52, no. 2, pp. 143-150, 2002.

[14] N. Hosonuma, M. Herold, V. De Sy et al., "An assessment of deforestation and forest degradation drivers in developing countries," Environmental Research Letters, vol. 7, 2012.

[15] E. M. Ordway, G. P. Asner, and E. F. Lambin, "Deforestation risk due to commodity crop expansion in sub-Saharan Africa," Environmental Research Letters, vol. 12, 2017.

[16] H. K. Gibbs, A. S. Ruesch, F. Achard et al., "Tropical forests were the primary sources of new agricultural land in the 1980s and 1990s," Proceedings of the National Academy of Sciences, vol. 107, no. 38, pp. 16732-16737, 2010. 
[17] P. Jagger and N. Kittner, "Deforestation and biomass fuel dynamics in Uganda," Biomass and Bioenergy, vol. 105, pp. 1-9, 2017.

[18] B. Gizachew, S. Solberg, and S. Puliti, "Forest carbon gain and loss in protected areas of Uganda: implications to carbon benefits of conservation," Land, vol. 7, no. 4, p. 138, 2018.

[19] R. Twongyirwe, M. Bithell, K. S. Richards, and W. G. Rees, "Three decades of forest cover change in Uganda's Northern albertine rift landscape," Land Use Policy, vol. 49, pp. 236-251, 2015.

[20] R. Twongyirwe, J. Majaliwa, P. Ebanyat et al., "Dynamics of forest cover conversion in and around Bwindi impenetrable forest, Southwestern Uganda," Journal of Applied Sciences \& Environmental Management, vol. 15, pp. 189-195, 2011.

[21] A. C. Otieno and M. Buyinza, "Collaborative forest management in Uganda: a strategy for controlling deforestation in west Bugwe forest reserve, Busia district," Research Journal of Applied Sciences, vol. 5, no. 5, pp. 337-344, 2010.

[22] C. A. Otieno, R. A. Kapiyo, B. O. Oindo, and M. Buyinza, "Politics and the enforcement of the Uganda forestry policy 2001: lessons from south busoga central forest reserve, mayuge district, eastern Uganda," Environmental Research Journal, vol. 6, no. 4, pp. 272-281, 2012.

[23] UBOS, The National Population and Housing Census 2014-Area Specific Profile Series, Kampala, Uganda, 2017.

[24] UBOS, National Population and Housing Census 2014, Uganda Bureau of Statistics: Kampala, 2014.

[25] UBOS, National Population and Housing Census 2014: Subcounty Report-Eastern Region, Uganda Bureau of Statistics, Kampala, Uganda, 2016.

[26] O. H. Adedeji, O. O. Tope-Ajayi, and O. L. Abegunde, "Assessing and predicting changes in the status of gambari forest reserve, Nigeria using remote sensing and GIS techniques," Journal of Geographic Information System, vol. 07, no. 03 , pp. 301-318, 2015

[27] O. O. Othow, S. L. Gebre, and D. O. Gemeda, "Analyzing the rate of land use and land cover change and determining the causes of forest cover change in gog district, gambella regional state, Ethiopia," Journal of Remote Sensing \& GIS, vol. 6, p. 219, 2017.

[28] NFA, National Biomass Study: Technical Report 2005 National Forestry Authority, Thirumulyvoyil, Chennai, 2009.

[29] FAO, National Forest Monitoring and Assessment-Manual for Integrated Field Data Collection, FAO, Rome, Italy, 2008.

[30] J. Townshend, "Effect of spatial resolution on the classification of land cover type," in Ecological Mapping from Ground, Air and Space, R. M. Fuller, Ed., pp. 101-112, Institute of Terrestrial Ecology, Huntigdon, UK, 1981.

[31] G. M. Foody and M. K. Arora, "Incorporating mixed pixels in the training, allocation and testing stages of supervised classifications," Pattern Recognition Letters, vol. 17, no. 13, pp. 1389-1398, 1996.

[32] J. R. Eastman, Guide to GIS and Image Processing, Vol. 1, Clark University, , Worcester, MA, USA, 2001.

[33] Millennium Ecosystem Assessment, Ecosystems and Human Well-Being: Synthesis, Island Press, Washington, DC, USA, 2005.

[34] J. G. M. Majaliwa, R. Twongyirwe, R. Nyenje et al., “The effect of land cover change on soil properties around kibale national park in south western Uganda," Applied and Environmental Soil Science, vol. 2010, Article ID 185689, 2010.

[35] S. Akello, N. Turyahabwe, P. Okullo, and J. G. Agea, "Land use/cover change and perceived watershed status in Eastern
Uganda," African Journal of Environmental Science and Technology, vol. 10, pp. 406-414, 2016.

[36] S. Solberg, J. May, W. Bogren, J. Breidenbach, T. Torp, and B. Gizachew, "Interferometric SAR DEMs for forest change in Uganda 2000-2012," Remote Sensing, vol. 10, no. 2, p. 228, 2018.

[37] J. B. Isunju and J. Kemp, "Spatiotemporal analysis of encroachment on wetlands: a case of Nakivubo wetland in Kampala, Uganda," Environmental Monitoring and Assessment, vol. 188, no. 4, p. 203, 2016.

[38] N. Turyahabwe, W. Kakuru, M. Tweheyo, and D. M. Tumusiime, "Contribution of wetland resources to household food security in Uganda," Agriculture \& Food Security, vol. 2, no. 1, p. 5, 2013.

[39] A. C. Otieno, M. Buyinza, R. A. Kapiyo, and B. Oindo, "Encroachment and deforestation in Uganda: a case of west Bugwe central forest reserve, Busia district," Research Journal of Applied Sciences, vol. 8, pp. 407-417, 2013.

[40] M. Kindu, T. Schneider, D. Teketay, and T. Knoke, "Drivers of land use/land cover changes in Munessa-Shashemene landscape of the south-central highlands of Ethiopia," Environmental Monitoring and Assessment, vol. 187, no. 7, p. 452, 2015.

[41] J. W. Bruce, Identifying and Working with Beneficiaries when Rights Are Unclear: Insights for REDD+ Initiatives, Program on Forests (PROFOR), Washington, DC, USA, 2012.

[42] B. Palmer Fry, "Community forest monitoring in REDD+: the "M" in MRV?" Environmental Science \& Policy, vol. 14, no. 2, pp. 181-187, 2011.

[43] L. Peskett, K. Schreckenberg, and J. Brown, "Institutional approaches for carbon financing in the forest sector: learning lessons for REDD+ from forest carbon projects in Uganda," Environmental Science \& Policy, vol. 14, no. 2, pp. 216-229, 2011.

[44] F. M. Kaboyo, "Forest management by the Nyangole community and Uganda forestry department," Second International Workshop on Participatory Forestry in Africa. Second International Workshop on Participatory Forestry in Africa Defining the Way Forward: Sustainable Livelihoods and Sustainable Forest Management through Participatory Forestry, pp. 173-176, FAO, Arusha, Tanzania, 2003.

[45] DELWP, Effective Engagement: Building Relationships with Community and Other Stakeholders. An Introduction to Engagement, The State of Victoria Department of Environment, Land, Water \& Planning, Victoria, Australia, 2015. 